Aisyah Journal of Informatics and Electrical Engineering Universitas Aisyah Pringsewu

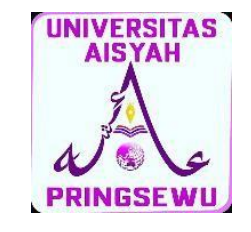

Journal Homepage

http://jti.aisyahuniversity.ac.id/index.php/AJIEE

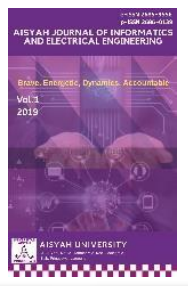

\title{
PENGGUNAAN MOTOR LISTRIK 3 FASA DALAM SISTEM FEEDDING FARM DI PT. CHAROEN POKPHAND JAYA FARM UNIT SERANG 2
}

\author{
Jihad Rahmat ${ }^{1}$, Irwanto ${ }^{2}$ \\ ${ }^{1,2}$ Program Studi Pendidikan Vokasional Teknik Elektro, Fakultas Keguruan Dan Ilmu Pendidikan \\ jihadrhmt@gmail.com ${ }^{1}$, Irwanto.ir@untirta.ac.id ${ }^{2}$
}

\begin{abstract}
Abstrak
Peternakan ayam di Indonesia pada saat ini kebanyakan masih bersifat konvensional. Penggunaan motor listrik 3 fasa ini memiliki tujuan untuk mempermudah pengusaha peternakan untuk pemberian pakan ayam yang biasanya dilakukan dengan cara menuangkan pakan pada ayam secara satu persatu menjadi sistem otomatis dalam pemberian pakan. Dalam hal ini pemberian pakan menjadi dapat terjadwal sehingga dibuatlah sistem fedding farm. Farm feeding system beroperasi untuk memberikan pakan kepada ayam secara otomatis berdasarkan jadwal yang sudah ditentukan. Pada analisa peneliti lakukan jadwal pemberian pakan dilakukan sebanyak 3 kali dalam sehari, dalam pengoperasian motor listriknya sendiri tidak mengalami kendala namun kendala yang terjadi terdapat pada jalur dan rantai yang digunakan sebagai penyaluran pakan pada ayam.
\end{abstract}

Kata kunci: feedding farm, motor listrik 3 fasa, pakan.

\section{PENDAHULUAN}

Peternakan di Indonesia semakin tahun semakin meningkat, hal ini dibuktikan bahwa setiap tahun permintaan pakan ternak semakin tinggi. Peternakan ayam di Indonesia masih bersifat konvensional, dalam pemberian pakan dilakukan masih secara manual yaitu dengan cara menuangkan pakan ke dalam tempat makan ayan secara satu persatu. Untuk meningkatkan hasil produksi ayam maka salah satu faktor yang diperhatikan adalah waktu pemberian pakan yang tepat dan terjadwal. Apabila sebuah perusahaan peternakan memiliki jumlah ayam dan kandang yang berskala besar seringkali menjadi kendala untuk menjaga ayam makan sesuai waktunya, selain itu pula saat pemberian pakan pada ayam juga memerlukan waktu yang banyak.
Pada saat ini permintaan peternak ayam untuk alat pendukung dalam kegiatan beternak sangat tinggi, diharapkan ada sebuah alat yang dapat membantu untuk mempermudah kegiatan beternak sehingga usaha peternakan ayam lebih produktif dan efisien. Dengan perkembangan teknologi yang semakin maju, fungsi dari tangan manusia dapat digantikan dengan mesinmesin modern salah satunya motor listrik 3 fasa. Dimana pemberian pakan ayam yang masih menggunakan tangan bisa digantikan dengan sebuah rangkaian sistem motor listrik, sistem ini digerakkan dengan sebuah motor listrik dengan daya 3 fasa yang dikontrol secara otomatis dengan bantuan komponen Time Dimer Relay (TDR). Dengan sistem ini tenaga dalam usaha peternakan ayam dapat berkurang, tetapi hasil produksi lebih meningkat. 
Motor induksi telah distandardisasi menurut karakteristik torsinya dari NEMA (National Electrical Manufactures Association), seperti desain A, B, C, D, atau F. Berbagai tipe motor tersebut memiliki karakteristik dan keunggulan masing-masing, maka pada penelitian ini juga dibuat perancangan program dan pengujian untuk mendapatkan karakteristik NEMA dari sebuah motor [1]. Sistem adalah obyek yang saling berinteraksi dan bekerja sama untuk mencapai tujuan logis dalam suatu lingkungan yang kompleks. Obyek yang menjadi komponen dari sistem dapat berupa obyek terkecil atau sub-sistem. Elemen lingkungan sistem memberikan peran yang sangat penting terhadap perilaku sistem sehingga komponenkomponen sistem berinteraksi untuk mengantisipasi lingkungan. Obyek penelitian merupakan suatu sistem dengan kerumitan yang lebih kompleks sehingga memerlukan ringkasan singkat. Salah satunya adalah dengan melakukan pemodelan dan membuat model dari sistem tersebut [2].

Motor induksi tiga fasa dengan daya besar tidak dapat dijalankan dengan cara dihubungkan langsung ke penyulang (sumber jala-jala). Hal ini disebabkan karena, akan menyerap arus yang sngat besar yaitu 6-8 kali arus nominalnya. Hal ini disebabkan karena pada saat start besarnya slip pada motor induksi adalah sama dengan 1 (satu), sehingga disaat slip $=1$ (satu), tahanan rotor kecil. Arus menjadi besar dan akan merusak motor itu sendiri atau terganggunya sistem instalasi tegangan akan turun. Di mana tegagan jatuh ini mengganggu kerja dari relai, kontaktor, nyala lampu, maupun peralatan elektronik dan komputer yang ada disekitarnya [3].

Motor listrik 3 fasa merupakan motor listrik yang banyak digunakan saat ini, terutama di dunia industri karena motor ini banyak tersedia dengan daya yang besar. Motor ini beroperasi secara normal dengan menggunakan sistem tenaga listrik AC 3 fasa. Pada daerah tertentu yang yang hanya tersedia sistem tenaga listrik 1 fasa, maka tidak mungkin mengoperasikan motor ini pada sistem 3 fasa. Oleh karena itu motor ini terpaksa dioperasikan pada sistem 1 fasa dengan menggunakan metode yang baik dan sederhan sehingga motor ini dapat dioperasikan dengan biaya yang rendah.

Dalam pemeliharaan sebelum dioperasikan (pra-pemeliharaan) memiliki tujuan untuk menjamin peralatan agar dapat beroperasi dengan baik dan efektif. Agar memudahkan pengecekan biasanya dibuat perencanaan pemeliharaan. Dalam hal ini, dapat berupa jadwal pembersihan, penggantian pelumas dan uji coba peralatan tanpa beban. Untuk pemeliharaan pencegahan ini biasanya dilakukan dalam kurun waktu satu minggu sekali dan tergantung pada kendala disetiap motor listrik di masing-masing kandang, dikarenakan untuk mesin motor listrik tiga fasa ini begitu penting yaitu sebagai penyaluran pakan ayam yang diiharuskan adanya pemeliharaan secara teliti baik dari mesin motor listrik tiga fasa ataupun dari material pendukung lainnya seperti rantai dan jalur rantainya.

Selanjutnya adapun pemeliharaan pemberian pelumas dikarenakan setiap peralatan yang berputar atau bergerak perlu diberi pelumasan. Fungsi pelumasan sendiri untuk memberikan perlindungan pada permukaan yang bergesekkan, mencegah keausan dan menjadi pendingin suhu dari akibat adanya gesekkan. Untuk bahan pelumasnya sendiri tergantung dari kebutuhan dan kendala yang dialami dari motor listrik itu sendiri.

Adapun tujuan penelitian ini adalah untuk menganalisa proses produksi, pemasangan, perawatan, dan perbaikan pada mesin pakan ternak (through).

\section{TINJAUAN PUSTAKA}

Motor induksi rotor sangkar tupai dibuat dalam 4 kelas berdasarkan National Electrical Manufacturers Association (NEMA).

1. Motor Kelas A

Motor kelas A mempunyai rangkaian resistansi rotor kecil, beroperasi pada slip sangat kecil yaitu kurang dari 0.01 dalam keadaan berbeban, motor kelas A digunakan untuk keperluan torsi start yang sangat kecil.

2. Motor Kelas B 
Motor kelas B digunakan untuk keperluan umum mempunyai torsi starting normal dan arus starting normal, regulasi kecepatan putar pada saat full load rendah dibawah 5\% dan torsi starting sekitar $150 \%$ dari rated, walaupun arus starting normal biasanya mempunyai besar $600 \%$ dari fullload.

3. Motor Kelas C

Motor kelas $\mathrm{C}$ mempunyai torsi starting yang lebih besar dibandingkan motor kelas B, arus starting normal, slip kurang dari 0.05 pada kondisi full load, torsi starting sekitar $200 \%$ dari rated, dan biasanya digunakan untuk konveyor, pompa, kompresor dan lain sebagainya.

4. Motor Kelas D

Motor kelas D mempunyai torsi starting yang besar dan arus starting relatif rendah, slip besar, pada slip beban penuh mempunyai efisiensi lebih rendah dibandingkan kelas motor lainnya dan torsi starting sekitar $300 \%$.

Adapun perbandingan antara setiap kelas, Motor induksi rotor sangkar tupai dapat dilihat pada Gambar 1 di bawah ini.

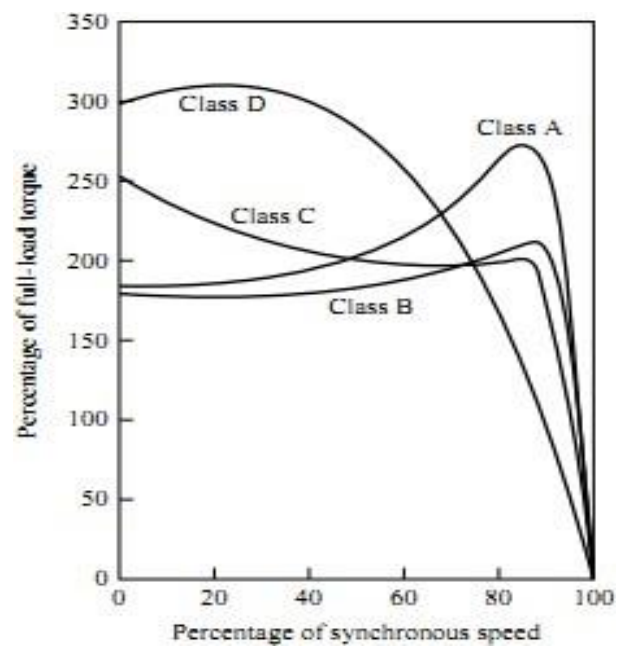

Gambar 1. Karakteristik torsi dan kecepatan pada motor induksi [1]

Teori kerangka referensi adalah metode yang akan mengubah arus, fluks, dan tegangan tiga phasa (berputar) ke bentuk dua phasa (berputar), metode ini digunakan untuk mempermudah analisa dan perhitungan. Persamaan tegangan dan torsi yang menggambarkan perilaku dinamis dari motor induksi adalah persamaan yang berubah terhadap waktu. Persamaan tersebut digunakan untuk menyelesaikan persamaan diferensial dan melibatkan beberapakompleksitas.

Perubahan variabel dapat digunakan untuk mengurangi kompleksitas persamaan ini dengan mengeliminasi semua induktansi yang berubah terhadap waktu, karena rangkaian listrik dalam gerak relatif, dari persamaan tegangan mesin. Dengan pendekatan ini, kumparan poly phase dapat dikurangi menjadi satu set dua kumparan fasa (dq) dengan sumbu magnetik dibentuk dalam kuadratur. Dalam kata lain, variabel stator dan rotor (tegangan, arus dan flux linkage) dari mesin induksi yang ditransformasi ke kerangka acuan, yang dapat berputar pada setiap kecepatan sudut atau tetap diam. Kerangka acuan biasanya dikenal dalam analisis mesin sebagai kerangka acuan sembarang.

Tahapan mengoperasikan motor pada dasarnya dibagi menjadi 3 tahap, yaitu:

1. Mulai jalan (starting)

Untuk motor yang dayanya kurang dari 4 $\mathrm{KW}$, pengoperasian motor dapat disambung secara langsung (direct on line). Untuk daya yang besar pengasutannya dengan pengendali awal motor (motor starter) yang bertujuan untuk meredam arus awal yang besarnya 5 sampai 7 kali arus nominal.

2. Berputar (running)

Beberapa saat setelah motor mulai jalan, arus yang mengalir secara bertahap segera menurun ke posisi arus nominal. Selanjutnya motor dapat dikendalikan sesuai kebutuhan, misalnya dengan pengaturan kecepatan, pembalikan arah perputaran, dan sebagainya.

3. Berhenti (stopping)

Tahap ini merupakan tahap akhir dari pengoperasian motor dengan cara memutuskan aliran arus listrik dari sumber tenaga listrik, yang prosesnya bisa dikendalikan sedemikian rupa (misalnya dengan pengamanan/break), sehingga motor dapat berhenti sesuai kebutuhan.

Untuk sistem jenis kendali motor listrik sendiri memiliki 3 macam Jenis kendali motor listrik, 
yaitu:

1. Kendali Manual

Instalasi listrik tenaga pada awalnya menggunakan kendali motor konvensional secara manual. Untuk menghubungkan atau memutuskan aliran arus listrik digunakan saklar manual mekanis, diantaranya adalah saklar togel (toggle switch). Saklar ini merupakan tipe saklar yang sangat sederhana yang banyak digunakan pada motor-motor berdaya kecil. Operator yang mengoperasikanya harus mengeluarkan tenaga otot yangkuat.

2. Kendali Semi Otomatis

Pada kendali semi otomatis, kerja opertaor sedikit ringan (tidak mengeluarkan tenaga besar), cukup dengan jari menekan tombol tekan start awal menggerakan motor dan menekan tombol stop saat menghentikan putaran motor. Untuk menghubungkan atau memutuskan aliran arus listrik menggunakan konduktor magnet, yang bisa dilengkapi rele pengaman arus lebih (Thermal Overload Relay) sebagai pengaman motor.

3. Kendali Otomatis

Dengan kendali otomatis, kerja operator semakin ringan, yaitu cukup memonitor kerja dari sistem, sehingga dapat menghemat energi fisiknya. Deskrepsi kerja dari sistem kendali otomatis dibuat dengan suatu program dalam bentuk rangkaian konduktor magnit yang dikendalikan oleh sensorsensor, sehingga motor dapat bekerja maupun berhenti otomatis.

Dalam menunjang proses produksi suatu industri pastinya banyak dipergunakan mesinmesin yang mempergunakan motor listrik sebagai penggerak utamanya. Motor listrik yang banyak dipergunakan biasanya motor listrik tiga fasa. Mengoperasikan motor induksi tiga fasa kita perlu mengetahui bagaimana mengontrol dan mengendalikan motor tersebut. Dalam pengendaliannya tergantung kepada penerapan yang digunakan di setiap industri masingmasing, baik itu dengan sistem manual dengan toggle switch, semi otomatis dengan kontaktor dan tombol tekan, maupun dengan sistem otomatis menggunakan kontaktor dan sensor. Semua itu bagaimana kebutuhan pada setiap industri masing-masing.
Di dalam instalasi kontrol motor selalu dibutuhkan suatu petunjuk operasi dan pemeliharaan. Standar Operasional Prosedur (SOP) kerja sangat dibutuhkan sebagai acuan dalam bekerja, sehingga bila ada kesalahan sistem yang keluar dari jalurnya akan bisa diidentifikasi.

Pemeliharaan merupakan fungsi yang penting dalam instalasi kontrol motor untuk menjamin kelancaran proses kerjanya juga untuk mencegah timbulnya kerusakan. Mesin atau peralatan yang digunakan secara terus-menerus pada suatu saat akan mengalami kerusakan, sehingga terjadi penurunan tingkat kesiapan dan penurunan kualitas performanya. Maka kegiatan pemeliharaan sangat dibutuhkan untuk memperpanjang usia peralatan [4].

Menurut referensi [5] dalam melakukan pemeliharaan, perlu adanya suatu manajemen pemilaharaan, dimana kita melakukan pengelolaan pekerjaan pemeliharaan melalui proses perencanaan, pelaksanaan hingga pengendalian dan evaluasi kerja pemeliharaan, hal ini dimaksudkan agar pemeliharaan tersebut, mampu menjaga atau mempertahankan kondisi sistem tetap baik dalam jangka waktu yang lebih panjang, dan selain itu juga dalam melakukan pemeliharaan, kita tidak akan banyak menggangu proses produksi yang nantinya akan menimbulkan kerugian bagi industri.

Dalam kegiatan pemeliharaan biasanya dibedakan menjadi dua bagian, yaitu pemeliharaan berencana dan pemeliharaan darurat. Namun, pada kenyataannya biasanya disebut dengan istilah yaitu:

1. Pemeliharaan pencegahan (preventive), yakni pemeliharaan yang dilakukan terhadap peralatan untuk mencegah kerusakan.

2. Pemeliharaan dengan cara perbaikan (corrective), yakni pemeliharaan yang dilakukan dengan cara memperbaiki dari peralatan (mengganti atau menyetel) untuk memenuhi kondisi standar peralatan tersebut.

3. Pemeliharaan jalan (running), yakni pemeliharaan yang dilakukan selama peralatan dipakai. 
4. Pemeliharaan dalam keadaan berhenti (shutdown) yakni, pemeliharaan yang dilakukan pada saat peralatan tidak sedang dipakai.

\section{METODE PENELITIAN}

Berdasarkan latar belakang dan pokok permasalahan maka, kajian ini akan memusatkan penelitian tentang "penggunaan motor listrik 3 fasa dalam sistem feeding farm di PT. Charoen Pokphand Jaya Farm unit Serang 2". Dalam hal ini penulis mempunyai sebuah ide untuk melakukan penelitian tentang penggunaan motor listrik 3 fasa yang digunakan sebagai sistem pemberi makan otomatis. Hal ini dilakukan agar peternak tidak harus memberikan pakan satu persatu pada kandang ayam karena sistem ini dapat dimanfaatkan oleh peternak untuk mempermudah pemberian pakan pada ayam sehingga hasil produksi ayam lebih produktif dan efisien.

Hal ini sesuai pendapat [6] menyatakan bahwa konsumsi pakan dapat mempengaruhi peningkatan pertambahan bobot badan yaitu semakin tinggi tingkat konsumsi pakan maka tinggi pula pertumbuhan bobot badannya, karena salah satu fungsi pakan dalam tubuh ayam selain untuk kebutuhan hidup pokok juga untuk pertumbuhan.

Pakan yang digunakan pada fase starter adalah pakan dengan kode $500 \mathrm{~J}$ untuk ayam umur 110 hari dan kode pakan $531 \mathrm{~J}$ untuk umur 10-28 hari dan kode pakan $532 \mathrm{~J}$ untuk umur 28 hari sampai umur produksi. Jenis pakan yang digunakan berbentuk crumble yang diproduksi oleh PT. Charoen Pokphand Indonesia. Pakan yang diberikan mengandung nutrisi yang cukup untuk kebutuhan ayam. Menurut referensi [7] menyatakan bahwa asupan nutrisi yang diberikan harus cukup dan memiliki kualitas pakan yang baik agar produksi telur yang dihasilkan optimal dan sumber utamanya dari pakan yang diberikan. [8] menyatakan bahwa ransum untuk ayam pembibit yang diberikan biasanya ransum yang mengandung protein $15 \%$ dan energy metabolis $2.900 \mathrm{kkal} / \mathrm{kg}$ seperti pada Tabel 1 di bawah ini.

Tabel 1. Kode pakan yang digunakan

Kode Pakan Umur Ayam

\begin{tabular}{cc}
\hline $500 \mathrm{~J}$ & 1 sampai 10 hari \\
$531 \mathrm{~J}$ & 10 sampai 28 hari \\
$532 \mathrm{~J}$ & 28 hari sampai produksi
\end{tabular}

\section{PEMBAHASAN}

Berikut ini adalah flowchart alur proses pengoperasian mesin through mulai dari menaruh pakan pada penampungan hingga ayam makan dapat dilihat pada Gambar 2 sebagai berikut ini.

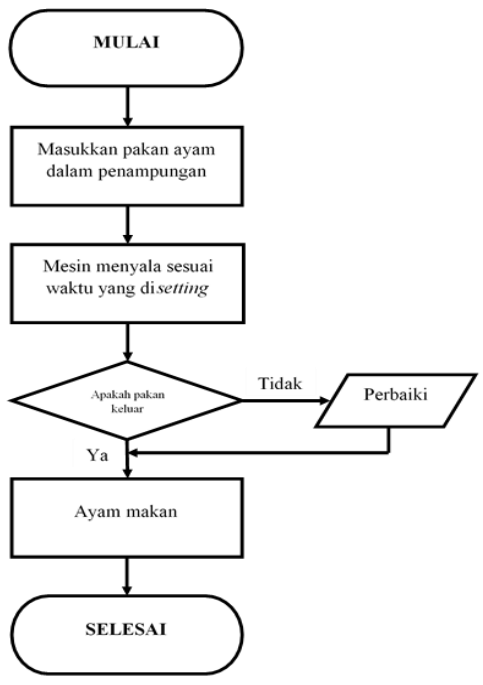

Gambar 2. Flowchart proses feeding farm

Dari Gambar 2 di atas dapat dipaparkan proses feeding farm di PT. Charoen Pokphand Jaya Farm unit Serang 2. Pertama adalah memasukkan pakan kedalam penampungan yang sebelumnya pakan sudah ditimbang dan diukur sesuai dengan porsi yang akan diberikan kepada ayam. Selanjutnya adalah penyettingan mesin yang mana disetting dengan bantuan alat Time Dimer Relay (TDR) yang kemudian mesin akan menyala dan mulai mengeluarkan pakan yang berada di dalam penampungan untuk disaluran melalui jalur yang sudah disediakan yang akan mengarah pada ayam. Apabila ketika mesin menyala namun pakan tidak keluar atau mengalami kendala ketika sedang beroperasi maka langsung dilakukan perbaikan dan dinyalakan kembali secara manual lalu kemudian ayam baru dapat makan. Apabila 
mesin tidak mengalami kendala maka ayam akan langsung dapat makan.

Spesifikasi motor 3 fasa yang digunakan pada mesin pakan di PT. Charoen pokphand Jaya Farm unit Serang 2 seperti pada Tabel 2 di bawah ini.

Tabel 2. Merk dan spesifikasi motor listrik

\begin{tabular}{|c|c|c|c|c|c|}
\hline \multirow{2}{*}{\multicolumn{6}{|c|}{$\begin{array}{l}\text { Erich Stallkamp } \\
\text { Dinklage/Germany }\end{array}$}} \\
\hline & & & & & \\
\hline \multicolumn{2}{|c|}{$\begin{array}{l}\text { TYPE N100A } \\
4 .\end{array}$} & \multicolumn{2}{|c|}{$\begin{array}{l}\text { Nr. } \\
090701131\end{array}$} & \multicolumn{2}{|c|}{$\begin{array}{l}\text { BAUFORM } \\
\text { B5 }\end{array}$} \\
\hline $\begin{array}{l}\text { I.KI. } \\
\text { F }\end{array}$ & IP. 55 & & 1 & PHA & \\
\hline $\begin{array}{l}\mathrm{k} \\
\mathrm{W}\end{array}$ & $\mathrm{V} \Delta / \mathrm{y}$ & $\mathrm{V} \Delta / \mathrm{y}$ & $\min _{-1}$ & $\mathrm{~Hz}$ & $\cos$ \\
\hline 2.2 & $230 / 400$ & $9.5 / 5.4$ & $\begin{array}{c}142 \\
0\end{array}$ & 50 & 0.80 \\
\hline 2.6 & $275 / 480$ & $9.5 / 5.4$ & $\begin{array}{c}170 \\
0\end{array}$ & 60 & 0.80 \\
\hline
\end{tabular}

\begin{tabular}{lll} 
MF. & IEC.3 & FO.3 \\
& 8 & 4 \\
\hline
\end{tabular}

Pada pengaplikasiannya motor listrik 3 fasa ini merupakan alat utama dalam mesin pakan karena digunakan sebagai penggerak rel atau rantai yang berfungsi sebagai penyalur pakan ayam pada jalur mesin pakan. Selain mesin pakan yang perlu diperhatikan juga yaitu berupa pakan ayam yang akan diberikan kepada ayam itu sendiri.

Pakan yang diberikan harus dapat memenuhi kebutuhan hidup pokok ayam dan sesuai dengan kebutuhan nutrisi serta umur ayam. Pakan juga memiliki kandungan-kandungan zat makanan yang dibutuhkan oleh ayam untuk keperluan hidup ayam seperti kandungan karbohidrat, lemak, mineral, protein, vitamin dan air. Hal ini sesuai dengan peraturan menteri pertanian bahwa pakan adalah bahan makanan tunggal atau campuran bahan pakan, baik yang diolah maupun tidak diolah, yang diberikan kepada hewan untuk kelangsungan hidup, berproduksi dan berkembang biak. Pakan diberikan sesuai dengan jumlah dan kebutuhan nutrisi ternak berdasarkan umur atau periode pertumbuhan seperti pada Gambar 3 di bawah ini.

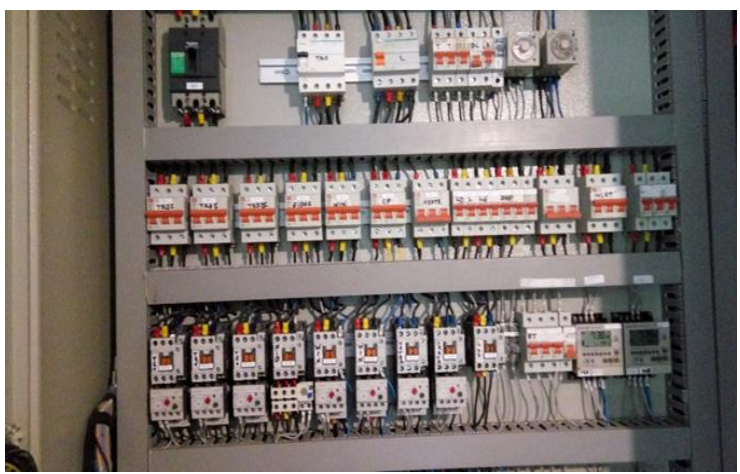

Gambar 3. Panel instalasi mesin pakan

Pada Gambar 3 di atas menunjukkan berupa rangkaian instalasi mesin through untuk penggunaan satu ruang kandang saja. Pada rangkaian diatas dapat dijelaskan bahwa mesin through mendapatkan sumber tegangan dari sumber listrik 3 fasa yang dimana dari sumber dihubungkan pada switch breaker yang kemudian disalurkan pada miniature circuit breaker (MCB) 3 phase lalu dilanjutkan disambungkan pada masing-masing kontaktor yang kemudian disambungkan pada thermal overload relay (TOR) selanjutnya disambungkan pada TDR kemudian barulah diteruskan pada motor listrik 3 fasa yang berada di dalam kandang.

Dalam panel box tersebut terdapat 3 buah instalasi yang digunakan pada mesin through dikarenakan jumlah mesin through yang digunakan didalam kandang berjumlah 3 buah mesin. Pada masing-masing mesin memiliki fungsinya masing-masing yang mana 1 buah untuk memberi makan pada area ayam betina dan 2 buah untuk memberi makan pada area ayam pejantan.

Namun selain pada panel box tersebut yang mana sebagai sumber utama untuk mesin through, didalam kandang pun terdapat duah buah saklar yang biasanya difungsi bila pada mesin through mengalami kendala atau kerusakan yang mengakibatkan mesin harus dihidupkan secara manual karena mengingat mesin tersebut dapat hidup pada settingan yang telah diatur pada TDR sehingga apabila mesin mengalami kerusakan dana yam belum mendapatkan makan maka mesin akan 
dihidupkan secara manual dengan menggunakan saklar yang berada di tiang dalam kandang seperti pada Gambar 4 di bawah ini.

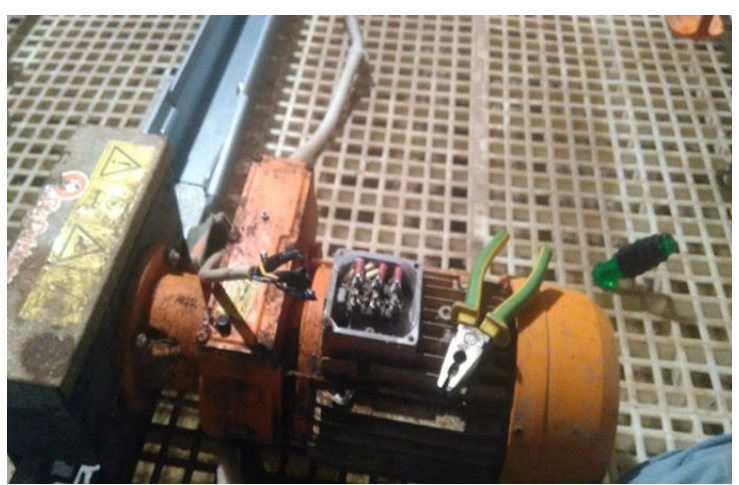

Gambar 4. Proses pemasangan motor listrik

Proses pemasangan ini dilakukan dengan menghubungkan kabel yang berasal dari panel depan yang bersumber listrik 3 fasa. Pada saat pemasangan kabel R S T dihubungkan langsung pada soket motor listrik sesuai penggunaannya sebagai forward atau reverse.

Sebelum dihubungkan pada sumber listrik terlebih dahulu dilakukan pemasangan pada jalur keluarnya pakan barulah kemudian peletakan mesin motor listrik sebagai penggerak utama mesin through. Pada satu jalur mesin pakan ini dapat menggerakkan rel dalam jalur pakan sepanjang \pm 120 meter. Dalam pemasangannya sendiri biasanya dalam satu area kandang terdapat 3 buat mesin pakan yang mana penggunaannya sebagai jalur pakan area ayam betina dan area ayam pejantan seperti pada Gambar 5 di bawah ini.

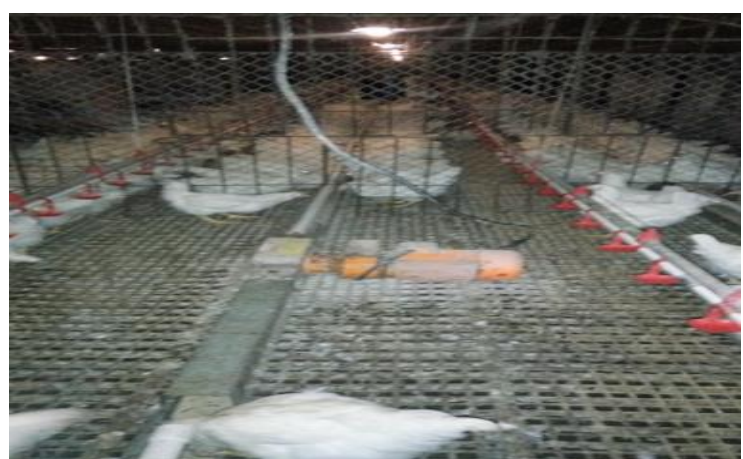

Gambar 5. Mesin pakan yang dioperasikan

Pada mesin pakan yang telah dioperasikan untuk peletakkannya sendiri motor listrik ditaruh dibagian bawah dan ditutupi oleh box kotak agar mesin aman dari gangguan ayam dan ayam pun aman tidak tersengat aliran listrik dari motor listrik itu sendiri.

Pada saat sistem pengoperasiannya ketika mesin menyala akan menjalankan rel yang berada pada jalur yang akan membawa pakan keluar dari penampungan dan mengisi jalurjalur mesin pakan dari ujung sampai ujung secara merata dengan pakan yang sebelumnya telah ditaruh didalam sebuah penampungan.

Untuk kendala yang dialami sendiri pada mesin through ini yang paling sering yakni putusnya rel yang berada didalam jalur mesin pakan dikarenakan dari kualitas rel itu sendiri yang sudah seharusnya diganti karena sudah banyak yang mengalami korosi yang mengakibatkan kekuatan dari rel itu sudah rentan sehingga mudah putus ketika mesin sedang beroperasi seperti pada Gambar 6 di bawah ini.

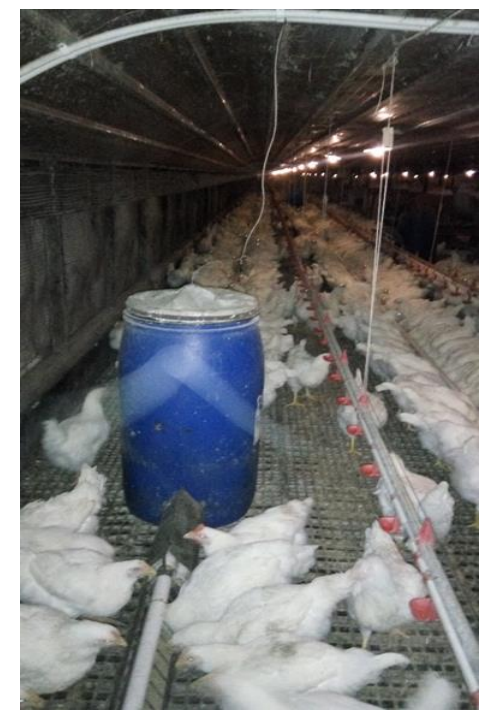

Gambar 6. Penampungan pakan ayam

Pada Gambar 6 di atas merupakan wadah penampungan pakan ayam, wadah tersebut terbuat dari drum yang telah dimodifikasi sebelumnya dan barulah dapat digunakan di dalam kandang sebagai penampungan pakan yang nantinya akan mengeluarkan pakan pada saat mesin pakan beroperasi [9].

Untuk sistem pengisian pakan pada penampungan ini menggunakan pakan berkode $532 \mathrm{~J}$ dikarenakan pengoperasian mesin pakan hanya untuk ayam dengan usia 28 hari sampai produksi. Untuk pengisiannya sendiri pakan 
yang dimasukkan ke dalam penampungan terlebih dahulu ditimbang sesuai dengan porsi yang akan diberikan sehingga ayam makan sesuai dengan porsinya agar ayam tidak mengalami pertumbuhan yang pesat karena apabila ayam mengalami kelebihan bobot akan berdampak buruk untuk hasil produksi yang dicapai seperti pada Gambar 7 di bawah ini.

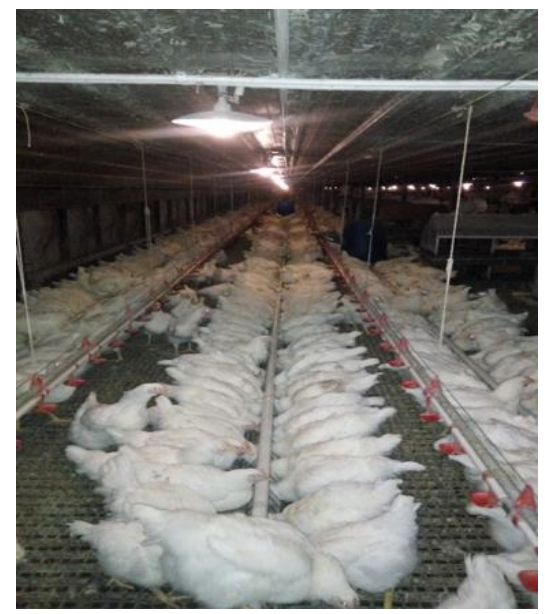

Gambar 7. Proses ketika ayam sedang makan Pada Gambar 7 di atas merupakan proses ketika ayam sedang makan. Ketika mesin pakan menyala secara otomatis maka ayam akan dengan sendirinya langsung berbaris disepanjang jalur mesin pakan untuk posisi makan. Untuk porsi yang diberikan pada ayamayam tersebut telah ditakar sesuai dengan kebutuhannya baik itu karbohidrat, protein, lemak, vitamin dan lainnya.

Untuk pakan yang keluar dari mesin pakan ini sendiri ketinggian pakannya didalam jalur telah diperhitungkan yaitu setinggi $2 \mathrm{~cm}$, berlaku dari depan area kandang hingga bagian belakang kandang dikarenakan agar bobot ayam pada bagian area depan dengan bagian area belakang memiliki bobot yang sama antara ayam satu dengan ayam lainnya, seperti pada Gambar 8 di bawah ini.

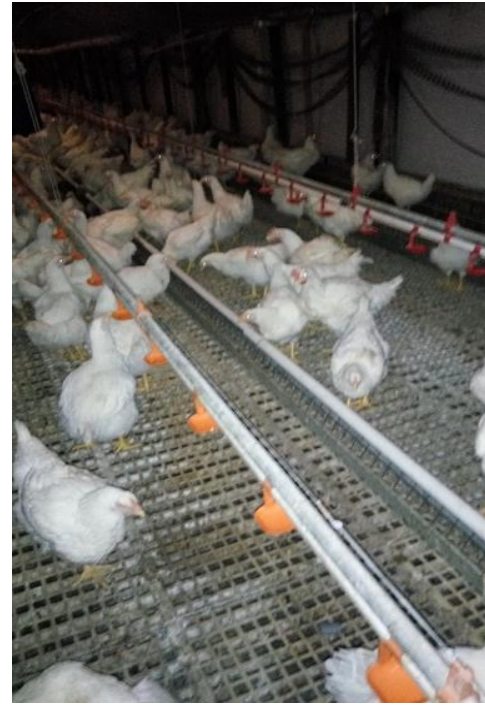

Gambar 8. Jalur mesin pakan.

Dari Gambar 8 di atas dapat dilihat berupa jalur mesin pakan yang bila sedang beroperasi akan membawa pakan dari penampungan untuk dimakan ayam dan bila mesin sedang tidak beroperasi kondisi didalam jalur mesin through akan kosong hingga nanti mesin beroperasi kembali dan jalur terisi oleh pakan ayam.

Pada jalur mesin pakan ini didalamnya terdapat sebuah rel atau bisa disebut juga rantai yang fungsinya untuk menyalurkan pakan dari bak penampungan sampai memenuhi seluruh jalur mesin pakan. Pada jalurnya sendiri ditutupi oleh besi berongga dikarenakan agar ayam-ayam tersebut tidak masuk dan tersangkut kakinya atau terbawa oleh rel atau rantai yang terdapat didalam jalur pada saat mesin sedang beroperasi, sehingga jalur mesin through harus ditutupi oleh besi-besi berongga sehingga tidak mengurangi dari fungsinya tersendiri.

\section{PENUTUP}

Dalam sistem feeding farm yang diterapkan pada PT. Charoen Pokphand Jaya Farm unit Serang 2 baik itu dalam sistem pemasangan, perawatan serta perbaikan yang dilakukan sudahlah cukup khususnya pada mesin pakan karena mesin ini merupakan penunjang penting untuk hasil produksi yang baik dikarenakan apabila mesin ini mengalami kerusakan dan tidak langsung ditangani maka ayam-ayam yang berada di dalam kandang akan mengalami kelaparan yang mengakibatkan timbulnya stress pada hewan dikarenakan kelaparan dan akan 
dapat berakibat fatal. Oleh karena itu maintenance yang dilakukan disana sangatlah ketat baik itu pada saat pemasangan hingga perawatan yang dilakukan secara rutin hampir setiap hari.

\section{DAFTAR PUSTAKA}

[1] Haryanto, H. 2014. Analisis karakteristik motor induksi tiga fasa XYZ standar NEMA.Universitas Sultan Ageng Tirtayasa Cilegon. Vol. 3 No.1.

[2] Kadaffi, M. 2011. Penerapan simulink untuk simulasi. Universitas Mercu Buana Jakarta.

[3] Putra, J. S. M. 2016. Pembuatan trainer instalasi motor 3 phase. Institut Keguruan dan Ilmu Pendidikan PGRI Madiun. Vol. 1 No. 2.

[4] Priyandono, B. 2015. Sistem pemeliharaan instalasi motor listrik pada mesin industri pengasutan bintang-segitiga dengan dua arah putaran. Bandung: Politeknik Bandung.

[5] Daryus, A. 2012. Manajemen pemeliharaan mesin. Jakarta: Universitas Darma Persada.

[6] Evalina, N. 2018. Pengaturan kecepatan putaran motor induksi 3 fasa menggunakan programmable logic controller. Universitas Muhammadiyah Sumatera Utara.Vol. 3 No. 2.

[7] Anthony, Z. 2014. Pengoperasian motor induksi 3 fasa hubungan delta pada sistem tenaga 1 fasa yang ditinjau dari efisiensi dan kemampuan motor. Institut Teknologi Padang.

[8] Kartasudjana, R. \& E. Suprijatna. 2006. Manajemen ternak unggas. Jakarta: Penebar Swadaya.

[9] Sembodo, B. P. 2012. Studi perencanaan proteksi motor listrik 3 fasa.Universitas PGRI Adi Buana Surabaya.Vol. 58 No. 1. 